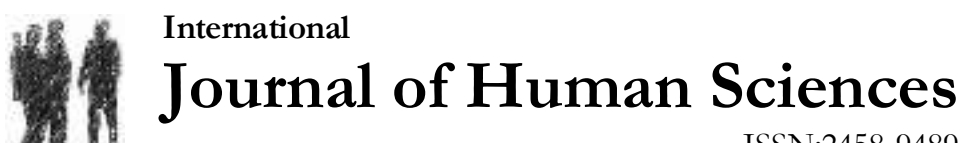 \\ ISSN:2458-9489
}

Volume 14 Issue 3 Year: 2017

\section{Factors affecting the success of internationally awarded Turkish chefs}

\author{
Serdar Eren ${ }^{1}$ \\ Osman Güldemir ${ }^{2}$
}

\begin{abstract}
Introduction

Over the past few decades restaurant business has boomed in Turkey. New styles and techniques are implemented to cuisine and chefs became more equipped in terms of skills and knowledge. However, there is a lack of a number of awarded Turkish chefs known in the international arena. Purpose:

This paper tries to identify the operational and cultural factors related to the absence of Turkish chefs and restaurants in the culinary world. The importance of this research is to analyze the reasons behind the success of Turkish award-winning chefs to help the young willing Turkish chefs throughout their career success paths to International Arena.

Method and material:

Semi-structured interviews are conducted with the award-winning Turkish chefs. The data gathered from the interviews are analyzed through the categorization of the factors previously found from the literature. Findings are discussed in this manner.

Results and Discussion:

Chefs' philosophies which shape the concepts of their restaurants is the most important factor for success, the philosophy also triggers the creativity and innovation. Selection of products and employee in terms of the availability, quality, and sustainability is another important factor. Most of the chefs are having a struggle in costs and pricing since this factor mostly relies on the cultural profile of the customers.
\end{abstract}

Keywords: Gastronomy; Culinary Arts; Turkish chefs; Restaurant success; Restaurant Awards.

\section{Introduction}

The importance of winning an award for a chef is an absolute form of personal satisfaction, imperceptible and risk-sensitive experience, serves to set a criterion of excellence and competitive environment (Edelheim et al., 2011). For instance, some studies stated that professionally evaluated awards are the most effective way of boosting the market success of Haute-Cuisine among chefs, restaurateurs, culinary experts, (Balazs, 2002, p. 248; Johnson et al., 2005, p. 171). It is also emphasized that having been published in a guidebook or gaining an award attracts the international clientele and serves to the higher profit margins but also effects the previous customers are lost (Snyder and Cotter, 1998). For a chef, gaining a good score, rating or an award

\footnotetext{
${ }^{1}$ Dr., Independent Research Chef, chefserdar75@gmail.com

2 Culinary Instructor, Anadolu University Faculty of Tourism, Department of Gastronomy and Culinary Arts, osmanguldemir@anadolu.edu.tr
} 
is recognition of exceptional skills and abilities. With respect to the behavior related articles (Frey, 2006; Frey and Neckermann, 2008), people are not only seeking for wealth but also strive for excellence, being accepted by a group of people and become famous for the quality of the work they have accomplished. Most of the chefs, being appreciated and getting attention with their cuisine, is more important than having a high income and this can only be achieved by getting great ratings from the evaluations. Some chefs live their lives under the stars, ratings, and evaluations. When a downgrading happens the results can be very destructive, as the example of the French three-star chef Bernard Loiseau suicide in 2003 because of he was downgraded from three stars to two (Mariani, 2003, p. 24; Ehrmann and Meiseberg, 2009).

International awards in Turkey started to appear with Beyti Restaurant by Chef and owner Beyti Güler who won the "International Gastronomy Awards" in Lisbon-Portugal, 1983. In 1986 Beyti Güler has gained itself a place "World's Best 40 restaurants Awards" in Cannes and also had the rank of "The Best Restaurant Europe" at the "World's Best 40 Restaurants Awards" in Paris, 1987 (http://earsiv.sehir.edu.tr).

One of the other remarkable international awards has given to Köşk Restaurant - Konya in 2003. Waitrose Food Illustrated Magazine rewarded the Köşk Restaurant as "Best 10 Restaurants of the World" because of the new concept named as "Sufi Cuisine" which is created and implemented by Nevin Halıc1, a well-known gastronomy professional and research chef in Turkey.

Mehmet Gürs, the Owner-Chef of Mikla Restaurant in Istanbul, appeared first in 2015 at the "World's Best Restaurants Guide", reached 40 steps to number 56th in 2016 and the 51st place in 2017. Within the same list, Neolokal Restaurant operated by Chef Maksut Asskar appeared at the "Diners Club New Discoveries" in 2017.

In 2005 First Turkish Michelin Star Chef Ali Güngörmüss appeared and gained lots of attention with his fine dining restaurant, Le Canard Nouveau, in Hamburg - Germany. Serkan Güzelçoban with his restaurant "Handicap" owns two Michelin star and the title of has the first and only Michelin star restaurant for disabled people in the world.

Some awards are given to restaurants, and the others may directly be given to chefs. In 2012 Aydin Demir, former executive chef of Feriye Palace Restaurant, located in Istanbul, has won "Les Toques Blanches du Mundo" award with his exceptional Turkish- Ottoman cuisine concepts.

Somer Sivrioğlu, Turkish-born Chef moved to Australia has gained a number of awards with his two restaurants "Anason" and "Efendy", such as 3 times RCNSW Winner of Specialty Restaurant 2011,2014 and 2015, 2014 Best Breakfast, Good Food Guide, 2013 Inner West Local Business Awards, Winner best restaurant, 2012 Taste of Sydney, Best in Taste Award, 2010 Inner West Business Awards-Best Restaurant, Gault \& Millau two toques.

\section{Literature Review}

The literature is reviewed through the way of understanding the stakeholders acting a significant role in the picture. The three stakeholders that provide a context for the study are as follows: Chefs Competencies, Restaurant success factors and Guides \& Awards Specifications.

\subsection{Chefs Competencies}

In the fine dining and Haute-Cuisine business, award winning chefs need to have higher levels of abilities and skills to create new dishes and maintain the quality. Birdir and Pearson (2000; 208) have identified the competencies of chefs by explaining it in the two separate focus as; research 
focused research chefs and management focused research chefs. The research focused research chefs who are capable of mastered skills and knowledge of ingredients, sauces, stocks and various cuisines to employ the new product development, recipe creation, and food testing. On the other hand, management focused research chefs are more related to product sales, and presentations which make them the major figure in strategic planning, and overall goals of the business. Knowledge of flavors, knowledge of food sanitation, ability to distinguish the level of quality in food products, general communication skills, and ability to make decisions were revealed as the most important chef competencies. Another important study has been accomplished by Zopiatis (2010) came with the factors such as; Professionalism, knowledge of culinary flavors, managerial skills (delegating and organizing), decision-making skills and appreciation of cost management.

Klosse and his friends proposed a study of culinary success factors which has a role of the chefs competencies these factors are; name and presentation fit the expectation, appetizing smell that fits the food, good balance in flavor components in relation to food, presence of umami, combination of hard and soft textures, high flavor richness (Klosse et al., 2004).

\subsection{Restaurant Success Factors}

Thinking of a restaurant as a product most common success factors are related to costs, finance, marketing and human relations. Most of the research has focused on identifying success factors; cash flow and undercapitalization (Parsa et al.2005) Among the few studies addressed the fine dining and haute cuisine restaurants success factors. A categorization of chefs contains the two types of chefs, for hire chefs and entrepreneur chefs, in terms of financial perceptions stated by Surlemont and friends, and suggested a paradox is that for-hire chefs see themselves as an artist whose main objective is to satisfy the patrons through their cuisine, by leaving the profitability objectives behind, (Surlemont et al, 2005). This type of perception can trigger other factors as financial distress, insufficient education of the owners, limited industry (if any) experience, selling an ego rather than the concept, lack of organization and focus, working environment and related factors; Working long hours alongside family members strained relations and added to stress levels, and practices of training staff (Camilo A. et al. 2008). Thus the problems related to single unit operations (cost controls, personnel training, and maintenance of facilities), standard operating procedures (sustainable information gathering and effective marketing strategy to reach the maximum productivity), multi-unit strategic planning (setting goals and executing plans), interpersonal and social responsibilities, travel and visiting units, Human Relations, effective leadership and unit level finances may occur (Di Pietro et al. 2007). In their study, Parsa et al. (2005) argued that the past research on restaurant failures focused mostly on quantitative factors and bankruptcy rates, however, there are other qualitative factors needs to be identified.

\subsection{Guides and Awards Specifications}

The Michelin Guide system, established in 1900, is based on a standardized system of fixed criteria (Bouty et al. 2012), based on anonymous inspections and independence, featuring a selection of best hotels and restaurants in all comfort and price categories. The guide is published annually with a standard classification assessment by recognizing the cultural differences among 21 countries worldwide (Johnson, et al., 2005; Ottenbacher and Harrington, 2007). No matter which cuisine style evaluated, Michelin stars are awarded to restaurants on five criteria: the quality of the products, mastering of flavors and cooking, the personality of the cuisine, value for money and consistency. One star is considered "a very good restaurant in its category", two stars reflect "excellent cooking, worth a detour" and three stars show "exceptional cuisine, worth a special journey" (Michelin, 2017). 
In addition to the awarding of stars, the Michelin Guide provides a written description of each locale and a variety of other symbols to give readers further insight into an establishment's ambiance, type of cuisine and specialties, and wine list, among other factors. In addition, the guide provides a comfort rating represented by the use of one to five forks and spoons for restaurants and one to five pavilions for hotels. These symbols take into consideration the decor, service, cleanliness, and upkeep of the surroundings (Subakti, 2013).

On the other Hand, "World Best Restaurants Guide" focuses only the chefs and restaurants to promote the business worldwide. The World's 50 Best Restaurants list, established in 2002, is not based on any explicit criteria for evaluation but has the alleged implicit criteria of 'novelty' and 'innovation.' It is constructed on an elaborate voting system performed by a group of international gastro-experts and resulting in a ranking list of the 'World's Best' restaurants (Cristensen and Pedersen, 2013). The Pellegrino's guide differentiates the listings through the continents like "Best 50 Asian Restaurants" or "Best 50 Latin America Restaurants". The guide also publishes a List of "Best 100 Restaurants" of the world.

The Gault Millau guidebook rate the restaurants on a scale of 0 to 20 by considering their geographic location and the history of the restaurant, quality of dishes, technical abilities, professionalism, cooking style, quality of ingredients, quality of wine and cellar, level of service and settings (Chossat and Gergaud, 2003).

\section{Purpose}

The purpose of the study is to understand the factors related to the success of internationally awarded Turkish chefs. The interviews conducted and the findings are discussed in the results section of the paper to seek and establish a clear path to young chefs and cooks to help with their career.

\section{Method and material}

The methodology of the paper is a case study. Case studies are a design of inquiry found in many fields, especially evaluation, in which the researcher develops an in-depth analysis of a case, often a program, event, activity, process, or one or more individuals. Cases are bounded by time and activity, and researchers collect detailed information using a variety of data collection procedures over a sustained period of time (Creswell, 2013).

First Phase of the study is the information gathered from the literature review. There are five key success factors identified by researchers. These are 1. Concept development and Innovation: Chef's philosophy, Thoughts, previous experience and his research process through the innovation and creativity 2. Product: availability, quality and sustainability 3. Finance: Costs and pricing 4. Staff: Availability and quality of the personnel, 5. Patrons: Overall cultural profile of the customers.

The second phase of the study comprises the on-site visits. Two researchers visited some of the chefs in their restaurants to focus on more in-depth interviews, took place in restaurants and conducting interviews with the award-winning chefs during three months between February and May 2017 in Turkey and Germany. Researchers are also used social media channels to conduct interviews with the Turkish chefs in Asia. Semi-structured interviews are used to identify the key concepts, thoughts, and ideas about the problem. Interviews recorded are converted into transcripts and the data gathered is analyzed by the categorization technique. The data is evaluated through the factors gathered from the literature. In semi-structured interviews, specific information is desired from all the respondents in which case there is a more structured section to the interview. But most of the interview is guided by a list of questions or issues to be 
explored, and neither the exact wording nor the order of the questions is determined ahead of time. This format allows the researcher to respond to the situation at hand, to the emerging worldview of the respondent, and to new ideas on the topic (Merriam \& Elizabeth, 2016, pp. 201-221).

\section{Results and Discussion}

Without no doubt, the most important success factor of an award-winning chef is to understand his/her philosophy about the cuisine. Ultimately, Sufi Cuisine invented and got awarded by Nevin Halic1 is one of the most significantly important findings of the study. The interview reveals that the abstraction of old ethical school principles to a modern cuisine reflects the creation of new ideas and concepts which are also assumed as chefs philosophy. Chefs philosophy reflects the ideas to create new dishes which shall be suitable with the concept and also the cultures related to the country where the restaurant is located in. Fatih Tutak, to give a clear example, was born in Turkey, worked with famous chefs since the age of 15 and became executive positions in restaurants and hotels then he decided to travel through Asia for a while to understand and experience the cuisines and ingredients of Asian culinary world. He works in Sathorn House Restaurant Bangkok which is nominated for the Best 50 restaurants list in 36th position in 2017 and he creates Asian dishes with a philosophy of Turkish Anatolian vision to create diversity in cuisine, on the other hand, Mehmet Gürs was born in Sweden, studied culinary arts in the USA. After having reliable working experience with various fusion cuisine chefs, he started with a quick casual restaurant, Touch Down - Nişantaş1, then upgraded to Fusion Mediterranean Cuisine with NuPera, Lokanta - Taksim and last he owns an Haute Cuisine restaurant, Mikla-Istanbul where he combines the European vision with Turkish ingredients and history. It is also very obvious that previous experiences, childhood memories, environments where chefs grew up also play a significant role in chef's philosophies. To illustrate that, Ali Güngörmüss, coming from Eastern Anatolian traditions, migrated to Germany when he was ten years old. What he reminds from the past is a blur, however, by considering the food that is cooked at home and the high population of the Turkish people living in the same childhood environment may make him strive to Authentic Turkish cuisine. His philosophy mirrors the idea of Turkish Migrant Cuisine with the European vision.

Finding and using the appropriate products and ingredients is the another important factor in award-winning restaurants success. During the field study, researchers categorized the chefs and restaurants in two different manners; Turkish restaurants in Turkey and Turkish Restaurants abroad to understand the matter of product in terms of availability, quality, and sustainability. The field research reveals that finding the quality local products in different seasons in abroad restaurants are relatively easier than the inland restaurants. By analyzing the menus and ingredients of the restaurants abroad (Australia, Thailand, and Germany), it's evident that the locally and seasonally fresh products are more demanding on markets and it's easier to reach the varietal and popular products by ordering it nearby countries. However; inland restaurants have the lack of finding appropriate products in season. One of the main reasons is that there is no demand for such gourmet products or people are not familiar with the usage and importance of the products that exist in Turkey. The other reason is the need of re-arranging the national agricultural planning which the Turkish Government is having serious attempts to conduct more sustainable plans to change it. To get rid of the shortage related with products Mehmet Gürs has hired an employee, former demi-chef at one of his restaurants who is an anthropologist and has a background in agricultural engineering. He traveled all around Anatolia to find the appropriate suppliers and ingredients during the research process before opening the Mikla restaurant.

The Methods and the new concepts play a significant role in restaurants success, most of the inspectors are assessing the new ingredients, the way chefs use and create new dishes, the way 
chefs use trends and ideas. It is supported by the literature that Michelin awarded restaurants are more into Classical French methodology with a small touch of new trends such as; molecular gastronomy(Akoğlu, Çavuş ve Bayhan, 2017), and ethnic cuisine and consumer differentiation ( Handicapped restaurant by Serkan Güzelçoban in Germany). However "Best 50 restaurants" awarded restaurants are more into the creation of the idea such as; using ancient methodologies, combining different ethnic cuisines, focusing on more fusional characteristics of the cuisine.

One of the inconsistent results of the study reveals the financial restrictions related to chef and owner. Chefs try to serve the best quality of taste and flavor which has a maximum cost and value, usually not accepted by the owners with a worry about selling it to the customer. Thus chefs often leave the idea of profitability behind their operations (Balazs, 2002; Surlemont et al.2005). On the other hand owners, pricing strategies rely mostly on the appearance of a guide book or award list. Prices tend to increase because of popularity; amenities provided and upgraded service (Synder\&Cotter, 1998). In an interview one Michelin star holder, Chef Ali Güngörmüss mentioned that he does not usually aim for a second Michelin star: Getting the second Michelin star has consequences related to the change of the cost structure, implementation of more research and serving the new customers which reveal more time energy and costs. This also affects the escalation of the prices and the decreased demand of previous customers (DW English, 2012). To get rid of the possible depth in between the stars chefs enlist coordinated moves such as writing cookbooks, generate media related activities (Blogs, Tv Programmes etc), catering or takeaways and consulting the other related companies (Surlemont et al, 2005). This rule may also apply significantly to Somer Sivrioğlu who wrote a book when he was opening his second establishment. The pricing strategies are also strongly related to the type of customers and their expectations on food-value considerations. There is a compelling difference of the profiles associated with the customers in inland and abroad restaurants. Turkish customers are more value oriented and price responsive than the Europeans meaning that they are not willing to pay to taste (e.g. signature dishes), they are willing to pay to get fed up with the meal. Thus, the consumer strategy of inland restaurants is becoming more international oriented.

On the road to success of award-winning restaurants, extensive training of knowledge and skills is a crucial factor that contributes to the high commitment of employees in the restaurant (Balazs, 2001). Field research and interviews reflect that it is easy to find skilled cooks but it's hard to train them in terms of the state of mind and thinking, creativity and sustainability. Gastronomy and Culinary arts schools and related higher education degrees are spread all around Turkey, however; there is a lack of standardization in teaching and curriculum. Students try to learn and become enthusiastic with the culinary field mostly with the theoretical knowledge which reflects the inappropriate skills and knowledge during the internship.

\section{References}

Akoğlu, A. Çavuş, O. Bayhan, İ. (2017). Michelin yıldızlı restoran şeflerinin moleküler gastronomi alg1 ve eğilimleri: San Sebastián, İspanya örneği. Journal of Tourism and Gastronomy Studies, 5(1), 43-59, DOI: 10.21325 /jotags.2017.58

Balazs, K. (2001). Some like it haute: leadership lessons from France's great chefs. Organizational Dynamics, 30(2), 134-148. https://doi.org/10.1016/S0090-2616(01)00048-1

Balazs, K. (2002). Take One Entrepreneur: The Recipe for Success of France's Great Chefs, European Management Journal, Volume 20, Issue 3, June, Pages 247-259. https://doi.org/10.1016/S0263-2373(02)00040-3 
Eren, S., \& Güldemir, O. (2017). Factors affecting the success of internationally awarded Turkish chefs. Journal of Human Sciences, 14(3), 2409-2416. doi:10.14687/jhs.v14i3.4655

Birdir, K., \& Pearson, T. (2000). Research chefs' competencies: a Delphi approach. International Journal of Contemporary Hospitality Management, 12(3), 205-209. http://dx.doi.org/10.1108/09596110010309989

Beauty, Isabelle, Marie-Leandro Gomez and Carole Drucker-Godard ( 2012). "Maintaining an institution: the institutional work of Michelin in haute cuisine around the world". Paper presented at the 8th New Institutionalism Workshop in Barcelona.

Camillo, A. A.; Connolly, J. D. \& Kim, G. W. (2008). Success and Failure in Northern California: Critical Success Factors for Independent Restaurants. Cornell Hospitality Quarterly, 49(4), 364-380. DOI: $10.1177 / 1938965508317712$

Christensen, B., \& Pedersen, J. (2013). Restaurant rankings in the culinary field. In B. Moeran \& B. Christensen (Eds.), Exploring Creativity: Evaluative Practices in Innovation, Design, and the Arts. Cambridge: Cambridge University Press.

CHOSSAT, V., \& GERGAUD, O. (2003). Expert Opinion and Gastronomy: The Recipe for Success. Journal of Cultural Economics, 27(2), 127-141. Retrieved from http://www.jstor.org/stable/41810815

Cotter, M. and W. Snyder. (1998). How Guide Books Affect Restaurant Behavior. Journal of Restaurant and Foodservice Marketing, 3, 69- 75. http://dx.doi.org/10.1300/J061v03n01_05

Creswell, J. W. (2013). Research Design: Qualitative, Quantitative, and Mixed Methods Approaches. USA: SAGE Publication.

DiPietro, R. B., Murphy, K. S., Rivera, M., \& Muller, C. C. (2007). Multi-unit management key success factors in the casual dining restaurant industry: A case study. International Journal of Contemporary Hospitality Management, 19, 524-536. http://dx.doi.org/10.1108/09596110710818275

Edelheim, J. R., Lee, Y. L., Lee, S. H., \& Caldicott, J. (2011). Developing a taxonomy of 'awardwinning' restaurants - What are they actually? Journal of QualityAssurance in Hospitality \& Tourism, 12(2), 140-156. http://dx.doi.org/10.1080/1528008X.2011.541815

Ehrmann, T., \& Meiseberg, B. (2009). Superstar Effects in Deluxe Gastronomy: an Empirical Analysis of Value Creation in German Quality Restaurants. KYKLOS, 62 (4), 526-541. DOI: 10.1111/j.1467-6435.2009.00449.x

Frey, B. S. (2006). Giving and receiving awards. Perspectives on Psychological Science, 1(4), 377-388. DOI: $10.1111 /$ j.1745-6916.2006.00022.x

Frey, B. S., \& Neckermann, S. (2008). Awards: A view from psychological economics. Journal of Psychology, 216, 198-208. http://dx.doi.org/10.1027/0044-3409.216.4.198

Johnson, C., B. Surlemont, P. Nicod and F. Revaz (2005). Behind the Stars: A Concise Typology of Michelin Restaurants in Europe. Cornell Hotel and Restaurant Administration Quarterly, 46, 170-187. https://doi.org/10.1177/0010880405275115

Klosse, P. R., Riga, J., Cramwickel, A. B., \& Saris, W. H. M. (2004). The formulation and evaluation of culinary success factors (CSFs) that determine the palatability of food. Food Service Technology, 4(3), 107-115. doi:10.1111/j.1471-5740.2004.00097.x

Mariani, J. (2003). The Agony of the Three-Star Restaurant, Restaurant Hospitality, 87, 24.

Merriam, S. B., \& Tisdell, E. J. (2016). Qualitative Research: A Guide to Design and Implementation (4th ed.). San Francisco, CA: Jossey-Bass

Ottenbacher, M. \& Harrington, R. (2007). The innovation development process of Michelinstarred chefs. International Journal of Contemporary Hospitality Management, 19, 444-460. http://dx.doi.org/10.1108/09596110710775110

Parsa, H. G., J. Self, D. Njite and T. King (2005). Why Restaurants Fail? Cornell Hospitality Quarterly, 46 (3), 304- 322. https://doi.org/10.1177/0010880405275598

Subakti, A.G. (2013). Overview Michelin star reputation restaurant in the hospitality industry, Binus Business Review, 4(1), 290-299. 

Sciences, 14(3), 2409-2416. doi:10.14687/ihs.v14i3.4655

Surlemont, B., \& Johnson, C. (2005). The role of guides in artistic industries: The special case of the "star system" in the haute-cuisine sector. Managing Service Quality, 15(6), 577-590. http://dx.doi.org/10.1108/09604520510634032

Surlemont, B., D. Chantrain, F. Nlemvo and C. Johnson (2005): Revenue Models in Haute Cuisine: An Exploratory Analysis. International Journal of Contemporary Hospitality Management, 17, 286-301. http://dx.doi.org/10.1108/09596110510597561

Snyder, W. and Cotter, M. (1998), The Michelin Guide and restaurant-pricing strategies, Journal of Restaurant \& Foodservice Marketing, 3(1), 51-67. http://dx.doi.org/10.1300/J061v03n01_04

Zopiatis, A. (2010). Is it art or science? Chef's competencies for success. International Journal of Hospitality Management, 29(3), 459-467. https://doi.org/10.1016/j.ijhm.2009.12.003

\section{Internet Sources:}

[DW English]. (2012, Dec 30). Talk with Star Chef Ali Güngörmüs | Talking Germany. [Video File]. Retrieved from https://www.youtube.com/watch?v=ejqwGNZP3tY

Şehir University Archives. (2017 April 11) Retrieved, April 11 from the şehir university website (http://earsiv.sehir.edu.tr:8080/xmlui/bitstream/handle/11498/3449/001502632006.pdf ? sequence $=3$ \&is Allowed $=\mathrm{y}$, gained access; 11.04.2017).

Michelin Travel. (2017, April 15). Retrieved April 15, 2017, from Michelin Travel Web Site http://www.viamichelin.com 